author applies his theoretical concepts of confrontational tension and 'forward panic' to various real-life, violent situations.

Despite these flaws, this is an original book and an excellent contribution to criminology, micro-sociology, sociology of emotions, psychology and other scientific disciplines. Although the writing style and the themes will limit its appeal mainly to scholars who specialize in the topic, Collins' short practical conclusions will also appeal to law-enforcement officials and policy makers.

\title{
Kristin Bumiller \\ In an Abusive State: How Neoliberalism Appropriated the Feminist Movement against Sexual Violence \\ Durham, NC: Duke University Press, 2008. xi + 215 pp. $\$ 79.95$ (hbk), $\$ 22.95$ (pbk). ISBN-13: 9780822342205 (hbk), ISBN-13: 9780822342397 (pbk).
}

\section{- Reviewed by Kathleen Daly, Griffith University, Brisbane, Australia}

In this theoretically imaginative and politically important book, Kristin Bumiller makes three interrelated claims. First, the social change agenda of the 1970s battered women's movement and anti-rape movement, which focused broadly on transforming the conditions of women's lives towards greater safety, security and autonomy, was contained and altered significantly in the 1980s and 1990s. Specifically, in the United States, with the shift to a neo-liberal political-economic regime and an increasingly punitive law-and-order environment, there emerged greater administrative controls over women seeking social welfare, along with an increasing focus on criminalization. Policies of criminalization, such as mandatory arrest for partner violence, had unintended consequences of bringing some women into the net as offenders. Celebrated media stories, such as the Central Park Jogger case in the early 1990s, re-enforced urban fears of racialized 'stranger danger', and served as an outlet for the public's demand for expressive (punitive) justice rather than rehabilitation or reintegration of offenders.

Second, the more recent international focus on gender violence in the developing world and in conflict and post-conflict societies, spawned by the United Nations and often using the language of human rights, may be subject to the same forces of containment. Specifically, it should not be assumed that gender violence in nations of the developing world can be addressed in the same way as in the United States (or other affluent democratic nations), which have differing legal systems, governance and security structures, family and kin-based social orderings and religious and cultural contexts. The idea of universal human rights may sound noble, but in practice, concrete attention must be given to local contexts and to mobilizing specific mechanisms that may be effective in addressing and reducing violence against women and children. 'Calling the police' and 'going to court' may not only be bad ideas and make things worse for women, these actions may not be remotely possible, despite what some NGOs are saying. Bumiller calls for 'the expression of meaningful human rights ... [which] emerges when the discourse of rights is conceived as contingent, fluid, and grounded in the deliberation of diverse individuals and groups rather than derived from universal principles' (p. 149). 
Third, with respect to what should be done, more administrative regulation of women's lives and more criminalization of men's violence are not recommended. Although there is a place for criminalization, Bumiller argues that social movement energies should be directed to 'promot[ing] the emotional well-being and economic sustainability of women who suffer [from gender violence] throughout their life span' (p. 163). The focus ought not to be solely on individual victims, but should look more broadly at the ways in which governments fail to 'prevent the full exercise of women's autonomy and freedom' (p. 164). Links between feminist and antiviolence movements need to be made. In doing so, connections can be drawn between state violence and interpersonal violence, and a broader social justice agenda can be established. Such an agenda would be concerned with 'police brutality, discrimination against immigrants, racism in all aspects of crime enforcement and in foreign wars' (p. 164), alongside violence against women and children.

I agree with Bumiller's claims and assessment. Since the late 1980s, other colleagues and I have challenged a sole focus on criminalization strategies to address partner violence; and we have emphasized that legal reform, by itself, cannot achieve significant change for victims of rape and sexual violence. Socio-historical analysis of 'women's complaints' in the 19th and 20th centuries by Ehrenrich and English (1978) show that experts' advice to women medicalized, individualized and pathologized broader public troubles. Although new technologies are used today to 'assess' and 'treat' violence against women and children (e.g. risk assessment inventories and a variety of forensic devices), there are striking parallels in Bumiller's analysis of professional and medical workers' stances towards women and those given in Ehrenrich and English. In the 1980s and 1990s, therapeutic interventions shifted away from a grassroots collective feminist model for many reasons. Among them, programmes needed to appear to be 'more professional' (p. 70) and to show evidence of 'success' (p. 95); this was coupled with a professional ethos of acting 'neutrally' and looking with heightened 'rationality' at violence (pp. 81-3).

Throughout the book, Bumiller is careful not to blame feminism or feminists for what went wrong; rather she calls for a more critical analysis of what happened and why, with the view of shifting feminist priorities and strategies in the future. On the need to shift priorities, I again concur. However, my sense is that our shared understanding of the problem and the way forward remains a minority viewpoint. Many still believe that a harsher criminal regime will deter men's violence against women and children; and despite Smart's (1989: 160) 'warning to feminism to avoid the siren call of law', many still say that more must be done to reform the law of rape in order to increase convictions and improve victims' experiences at trial. These beliefs in the efficacy and symbolic strength of criminal law to change people's behaviour, and in the potential for more legal reform, are visceral and resistant to change. Many feminist and victim advocates do not want to 'let go' of a criminalizing strategy because among other things, it appears to re-privatize partner violence and to lose a potential source of vindication for victims. On the international arena, like Bumiller, I too am concerned that we should not be exporting the standard western package of human rights talk and violence against women policies to the developing world. We would do better to learn from women's groups in emerging nations about the approaches they are developing, both within civil society and legal- 
state institutions, to change gender relations and the conditions that spawn violence against women and children.

I applaud the reach and depth of Bumiller's analysis and her call for a radical re-appraisal. Everyone should read this book for its message of critical reflection on past and present practices, and the need for a future agenda that is informed by social justice principles. However, I had two concerns, although neither takes away from the force of her argument.

One is how the term 'sexual violence' is used. Both in the sub-title to the book and in general claims about social movements to address gender violence, Bumiller uses the term 'sexual violence' to include sexual violence and non-sexual violence in on-going relationships (i.e. 'battering' or 'partner violence'). She does not explain this choice at the start of the book; and thus, one can be confused about which group of women or violent contexts she is referring to. Perhaps there has been a shift in terminology that I am unaware of, but I believe that gender violence would have been a better term for the book's sub-title and in general discussions of violence against women in the text.

A second is Bumiller's political analysis: she credits the shift to a neo-liberal political-economic regime in the late 1970s as a driving force in curtailing and derailing a more progressive feminist agenda. Her analysis could have been strengthened by drawing more on debates within criminology on contrary penal developments. For example, O'Malley (1999: 185) suggests that we understand contemporary penality, particularly its contradictory and volatile character, as arising from two strands of New Right thinking: a neo-liberal strand, which called for fewer restraints on the free market; and a neo-conservative strand, which called for greater discipline and social authoritarianism. Although the two are commonly referred to as 'neo-liberal', O'Malley argues that they are distinctive rationalities: one is concerned with creating 'subjects who are innovative and enterprising' (p. 177), who can, for example, take responsibility for preventing their victimization; the other 'privileges law and order as crucial, more so than the market and the individual' (p. 186), as a means to 'remoralize' society (p. 190). Feminist social movements against gender violence were altered and re-moulded by both rationalities, not just one; and it is important to see their distinctive and contradictory influences. Furthermore, a punitive law-and-order orientation was especially strong in the United States, stronger than in other affluent democratic nations; and the United States social welfare system was subject to even greater dismantling. Thus, Bumiller's book chronicles significant shifts in priorities, policies and practices concerning gender violence in the United States, in particular. Although such shifts have occurred in other nations, they have not been as strong or entrenched.

\section{References}

Ehrenrich, B. and D. English (1978) For Her Own Good: 150 Years of the Experts' Advice to Women. Garden City, NY: Anchor Press.

O’Malley, P. (1999) 'Volatile and Contradictory Punishment', Theoretical Criminology 3(2): 175-96.

Smart, C. (1989) Feminism and the Power of Law. London: Routledge. 